Disclaimer:

This document is a pre-print version of the manuscript that was subsequently peer-reviewed and accepted for publication by the journal Applied Microbiology and Biotechnology (2017). The final publication is available at Springer via http://dx.doi.org/10.1007/s00253-017-8522-z.

\title{
Biobutanol production from apple pomace: The importance of pretreatment methods on the fermentability of lignocellulosic agro- food wastes
}

\author{
María Hijosa-Valsero ${ }^{1 *}$, Ana I. Paniagua-García ${ }^{1,2}$, Rebeca Díez-Antolínez ${ }^{1,2}$ \\ ${ }^{1}$ Centro de Biocombustibles y Bioproductos, Instituto Tecnológico Agrario de Castilla \\ y León (ITACyL), Villarejo de Órbigo, E-24358, León, Spain \\ ${ }^{2}$ Instituto de Recursos Naturales (IRENA), Universidad de León, Avenida de Portugal \\ 42, E-24071, León, Spain
}

*Corresponding author:

E-mail: hijvalma@itacyl.es; mhijv@unileon.es

ORCID-ID: 0000-0001-9803-2585

Telephone: $(+34) 987374554$

Fax: $(+34) 987375893$

\begin{abstract}
Apple pomace was studied as a possible raw material for biobutanol production. Five different soft physicochemical pretreatments (autohydrolysis, acids, alkalis, organic solvents and surfactants) were compared in a high pressure reactor, whose working parameters (temperature, time and reagent concentration) were optimised to maximise the amount of simple sugars released and to minimise the generation of inhibitors. The pretreated biomass was subsequently subjected to a conventional enzymatic treatment to complete the hydrolysis. A thermal analysis (DSC) of the solid biomass indicated that lignin was mainly degraded during the enzymatic treatment. The hydrolysate obtained with the surfactant PEG $6000(1.96 \% \mathrm{w} / \mathrm{w})$ contained less inhibitors than any other pretreatment, yet providing $42 \mathrm{~g} / \mathrm{L}$ sugars at relatively mild conditions $\left(100{ }^{\circ} \mathrm{C}, 5 \mathrm{~min}\right)$, and was readily fermented by Clostridium beijerinckii CECT 508 in $96 \mathrm{~h}(3.55 \mathrm{~g} / \mathrm{L}$ acetone, $9.11 \mathrm{~g} / \mathrm{L}$ butanol, $0.26 \mathrm{~g} / \mathrm{L}$ ethanol; $0.276 \mathrm{~g} / \mathrm{g}_{\mathrm{S}}$ yield; $91 \%$ sugar comsumption). Therefore, it is possible to optimise pretreatment conditions of lignocellulosic apple pomace to reduce inhibitor concentrations in the final hydrolysate and perform successful $\mathrm{ABE}$ fermentations without the need of a detoxification stage.
\end{abstract}

\section{Keywords:}

Apple pomace; lignocellulosic wastes; pretreatment; ABE fermentation; biorefinery; DSC 


\section{Introduction}

The world production of apples in 2014 attained 84,630,275 tonnes; of which $13,093,335$ tonnes were harvested in the European Union (FAOSTAT 2016). It is estimated that $25-30 \%$ of the apple production is destined to apple processing industries, where apples are mainly used for juice extraction (Dhillon et al. 2013). Apple pomace is the solid waste generated after milling and pressing, and it constitutes 25-30\% of the total processed biomass (Dhillon et al. 2013). The average generation of apple pomace in the EU-28 between 2010 and 2013 reached about 1,053,000 tonnes/year (Ćosić et al. 2016). Apart from their evident application as animal and human food (Sudha et al. 2007), apple residues can be suitable feedstocks for biorefineries, due to their high carbohydrate content. Apple residues with high concentrations of free monosaccharides, like wet apple pomace, discarded apples, filtration sludge or juice of rotten apples, have been assessed for the generation of bioethanol (Tahir and Sarwar 2012) and biobutanol (Voget et al. 1985; Jesse et al. 2002; Maiti et al. 2016). However, to the best of our knowledge, apple pomace with high lignocellulosic contents has never been successfully fermented.

Industrial butanol production between 1920 and 1960 was based on the fermentation of carbohydrate-rich substrates (grain, molasses, potatoes, etc.) by solventogenic strains of Clostridium sp. in a process known as the acetone-butanol-ethanol (ABE) fermentation (Jones and Woods 1986). Due to the elevated costs of the abovementioned substrates, this fermentative route was abandoned after the consolidation of petrochemistry, which allowed the chemical synthesis of butanol from propylene (Chen et al. 2013). However, the development of new technologies which could enable the use of low-cost feedstocks might make the ABE fermentation profitable and interesting again (Jang et al. 2012, Jurgens et al. 2012), especially for those countries without crude oil reserves. Agro-food wastes, such as apple pomace, are composed of lignocellulosic biomass with high proportions of complex carbohydrates, like cellulose and hemicellulose. Solventogenic bacteria that have been traditionally used for ABE fermentation ( $C$. acetobutylicum, $C$. beijerinckii, etc.) are not able to directly ferment these polysaccharides (cellulose and hemicellulose). Because of that, an expensive pretreatment is required to release fermentable simple sugars (mainly glucose and xylose) from the intricate lignocellulosic fibre network. Generally, the pretreatment begins with a physicochemical process to alter the lignocellulosic structure (Salehi Jouzani and Taherzadeh 2015), followed by an enzymatic hydrolysis of the polysaccharides. As a consequence, at present it is not economically feasible to transform lignocellulosic residues into butanol at an industrial scale. It is therefore essential to find a cost-effective pretreatment which can release simple sugars from agro-food wastes.

Autohydrolysis is a pretreatment technique for lignocellulosic biomass consisting of the use of hot water or steam as a single reagent. Its advantages are that corrosion problems are limited, no sludges are generated and capital and operational costs are low (Garrote et al. 1999). Hydronium ions from both water and in situ-generated compounds (acetic, uronic and phenolic acids) catalyse the hemicellulose depolymerisation without significantly degrading cellulose and lignin (Garrote et al. 1999). Autohydrolysis has a wide range of applications, like pulping processes, defibration for fibreboard production and as a pretreatment for the enzymatic hydrolysis of cellulose (Garrote et al. 1999). It has been employed as a pretreatment for agriculture and food wastes, like corn stover or coconut shell in ethanol fermentation processes (Buruiana et al. 2014, Gonçalves et al. 2015), or pine and elm wood in ABE fermentation processes (Amiri and Karimi 2015). Dilute chemical pretreatments consist of the use of an aqueous solution containing a 
chemical reagent which can improve the degradation or hydrolysis of lignocellulosic biomass. These processes usually take place at high temperatures (above $120{ }^{\circ} \mathrm{C}$ ), but lower temperatures can also be employed when working with high-pressure reactors. The best-known dilute chemical pretreatments imply the use of acids (Lloyd et al. 2005, Orozco et al. 2013) or alkalis (Jurgens et al. 2012, Guilherme et al. 2015), but other reagents such as organic solvents (Araque et al. 2008, Mesa et al. 2011) and surfactants (Kapu et al. 2012, Wei et al. 2011) have been evaluated too. Experimental butanol production from agro-food wastes has been reported for sulfuric acid pretreatments (Qureshi et al. 2010) and $\mathrm{NaOH}$ alkaline pretreatments (Gao and Rehman 2014).

In the present work, apple pomace was studied as a possible raw material for biobutanol production. Five different soft physicochemical pretreatments (autohydrolysis, acids, alkalis, organic solvents or surfactants) with several reagents were compared in a high pressure reactor; with a biomass-to-solvent ratio of $10 \%(\mathrm{w} / \mathrm{w})$. Working parameters of the reactor (temperature, time and reagent concentration) were optimized via Response Surface Methodology (RSM). The pretreated biomass was subsequently subjected to a conventional enzymatic treatment to complete the hydrolysis. The main objective of these pretreatments was to maximise the amount of simple sugars released and to minimise the generation of fermentation inhibitors, in order to assess the fermentability of the hydrolysates with the strain $C$. beijerinckii CECT 508, which is adequate for the metabolisation of glucose/xylose mixtures. In addition, the transformations experienced by the solid biomass throughout the pretreatment were evaluated by differential scanning calorimetry (DSC).

\section{Material and methods}

\section{Chemicals and reagents}

Analytical grade $\mathrm{H}_{2} \mathrm{SO}_{4}, \mathrm{HCl}, \mathrm{NaOH}$ and $\mathrm{KOH}$; chemical pure grade $\mathrm{HNO}_{3}$; and HPLC grade methanol were obtained from Panreac (Castellar del Vallès, Spain). Analytical grade ammonia solution and ethanol were supplied by Scharlab (Sentmenat, Spain). Tween 80 and HPLC grade acetone were purchased from Sigma-Aldrich (Steinheim, Germany). Polyethylene glycol 6000 (PEG 6000) was provided by Acros Organics (Geel, Belgium). Cetyltrimethylammonium bromide (CTAB) was obtained from Ankom Technologies (Macedon, NY, USA).

The enzyme Celluclast 1.5L was supplied by Novozymes (Bagsvaerd, Denmark) and Cellic CTec2 was provided by Novozymes (Tianjin, China). The measured enzymatic activities were $88 \mathrm{FPU} / \mathrm{mL}$ for Celluclast $1.5 \mathrm{~L}$ and $124 \mathrm{FPU} / \mathrm{mL}$ for Cellic CTec2.

\section{Biomass description and processing}

Dry apple pomace was provided by Muns Agroindustrial S.L. (Lleida, Spain) in June 2016. The biomass was ground in a SM100 Comfort rotary mill (Retsch GmbH, Haan, Germany) and sieved to a size of 0.5-1.0 mm.

Moisture, ash, structural carbohydrates (cellulose and hemicellulose) and Klason lignin were analysed according to the National Renewable Energy Laboratory procedures (NREL 2008, 2012). Proteins were analysed with the Kjeldahl method, considering a conversion factor of 6.25. Fats were quantified in an ANKOM XT15 extraction system 
(AnkomTechnology). Total phenolic compounds were analysed following the method described by Folin and Denis (1912) after an extraction according to Xu et al. (2011). The chemical composition of apple pomace can be found in Table 1.

Table 1. Chemical composition of the studied apple pomace.

\begin{tabular}{|l|c|}
\cline { 2 - 2 } \multicolumn{1}{c|}{} & Apple pomace \\
\hline Total carbohydrates (\%) & 55.86 \\
\hline Soluble carbohydrates (\%) & 15.55 \\
\hline Cellulose (\%) & 21.22 \\
\hline Hemicellulose (\%) & 14.75 \\
\hline Klason lignin (\%) & 18.50 \\
\hline Protein (\%) & 4.87 \\
\hline Fats (\%) & 1.42 \\
\hline Ash (\%) & 1.31 \\
\hline Moisture (\%) & 6.56 \\
\hline Total phenolic compounds (mg/g) & 3.5 \\
\hline
\end{tabular}

The effect of the pretreatments on the solid biomass was assessed with a differential scanning calorimeter (DSC) STARe System DSC823e (Mettler-Toledo, Columbus, OH, USA). Three different solid samples were considered in each case: original biomass, biomass after the physicochemical treatment and biomass after the enzymatic hydrolysis. For the DSC measurement, all samples were dried at $45{ }^{\circ} \mathrm{C}$ until constant weight. Then, 7-10 mg biomass were introduced in a $40-\mu 1$ aluminium crucible and covered with a pierced lid. The crucible was placed in the DSC furnace and heated from 25 to $600{ }^{\circ} \mathrm{C}$ at a rate of $20^{\circ} \mathrm{C} / \mathrm{min}$. The system was continually flushed with gaseous $\mathrm{N}_{2}$ at $50 \mathrm{~mL} / \mathrm{min}$.

\section{Pretreatment}

Preliminary selection of the most suitable chemical compounds for the physicochemical treatment

In order to choose the most appropriate chemical compound for the physicochemical treatment of apple pomace, twelve different substances belonging to four general groups (acids, alkalis, organic solvents and surfactants) were solved in distilled water and compared. This preliminary selection was not applied to autohydrolysis, because that treatment does not require reagents.

Ten grammes of dry biomass were introduced in a glass bottle and $90 \mathrm{~g}$ aqueous solution containing one of the tested substances were added. The bottle was closed in a nonairtight manner so that gases could escape. Then, the bottle was placed in an autoclave at $121{ }^{\circ} \mathrm{C}$ during $2 \mathrm{~h}$. The experiments were performed in triplicate. The selected compounds and their dosages were: $2 \% \mathrm{H}_{2} \mathrm{SO}_{4}, 2 \% \mathrm{HCl}, 2 \% \mathrm{HNO}_{3}$ (acids), $2 \%$ $\mathrm{NaOH}, 2 \% \mathrm{KOH}, 2.5 \% \mathrm{NH}_{4} \mathrm{OH}$ (alkalis), $40 \%$ ethanol, $40 \%$ methanol, $40 \%$ acetone (organic solvents), 3\% Tween 80, 3\% PEG 6000, and 3\% CTAB (surfactants) (expressed in \%, w/w; referred to the total mass of $100 \mathrm{~g}$ mentioned above).

After the autoclave pretreatment, an enzymatic hydrolysis was performed inside the bottles as follows. The bottles were allowed to cool down, and then a 5-mL solution containing $0.97 \mathrm{~g}$ citric acid was added. In the case of samples treated with organic solvents, a small but significant mass of sample had evaporated inside the autoclave; 
and this loss was compensated by adding an equivalent mass of distilled water in this step. The $\mathrm{pH}$ was adjusted to 5.0 with a concentrated $\mathrm{NaOH}$ or $\mathrm{HCl}$ solution. This made a buffer citrate of about $50 \mathrm{mM}$ and $\mathrm{pH}$ 5.0. Afterwards, $409 \mu \mathrm{l}$ of the enzyme Celluclast $1.5 \mathrm{~L}$ were added. The bottles were capped and placed in an orbital shaker at $50{ }^{\circ} \mathrm{C}$ and $180 \mathrm{rpm}$ during $72 \mathrm{~h}$. At the end of the enzymatic hydrolysis, the sample was filtered through a nylon mesh and the liquid was centrifuged at $4100 \mathrm{rpm}$ during $10 \mathrm{~min}$ (centrifuge Jouan CR3i, Château-Gontier, France). For the chemical analyses of sugars and inhibitors, each liquid sample was filtered through a nylon syringe filter $(0.20 \mu \mathrm{m}$ pore; Agilent, Santa Clara, CA, USA) and analysed according to the procedure described in section Chemical Analyses.

The most efficient reagent of each group was selected (i.e. one acid, one alkali, one organic solvent and one surfactant) to perform an optimization of the pretreatment conditions as explained in the next subsection.

\section{Optimisation of pretreatment conditions}

Pretreatments were performed with a high-pressure 2-L reactor made of alloy Carpenter-20 (Parr Instrument Company, Moline, IL, USA). Similarly, a biomass ratio of $10 \%(\mathrm{w} / \mathrm{w})$ was also used. Forty grammes of dry biomass were placed in the reactor container and $360 \mathrm{~g}$ of the corresponding aqueous solution were added. The reaction mixture was heated at a rate of about $7.6^{\circ} \mathrm{C} / \mathrm{min}$ with continuous stirring, until the programmed working temperature was attained. Then, the reactor was kept at that temperature during a certain time. Time zero was considered at the beginning of the isothermal stage. At the end of the process, the reactor was cooled and the solid/liquid mixture was recovered. For working temperatures and times, see Table 2.

Table 2. General characteristics of the Complete Central Design experiments performed to optimize the physicochemical pretreatment of apple pomace.

\begin{tabular}{|c|c|c|c|c|c|}
\hline & $\begin{array}{l}\text { Factors } \\
\text { (variables to } \\
\text { optimize) }\end{array}$ & Runs & $\begin{array}{l}\text { Number of cube, } \\
\text { central and axial } \\
\text { points }\end{array}$ & Alpha & Axial ranges \\
\hline Autohydrolysis & 2 & 13 & $4,5,4$ & 1.41421 & $\begin{array}{l}T\left({ }^{\circ} \mathrm{C}\right): 120-220 \\
t(\min ): 5-120\end{array}$ \\
\hline Acids & 3 & 20 & $8,6,6$ & 1.68179 & $\begin{array}{l}T\left({ }^{\circ} \mathrm{C}\right): 100-200 \\
\mathrm{t}(\mathrm{min}): 5-120 \\
\text { Acid }(\%, \mathrm{w} / \mathrm{w}): 0.5- \\
3.5\end{array}$ \\
\hline Alkalis & 3 & 20 & $8,6,6$ & 1.68179 & $\begin{array}{l}T\left({ }^{\circ} \mathrm{C}\right): 100-200 \\
\mathrm{t}(\mathrm{min}): 5-120 \\
\text { Alkali }(\%, \mathrm{w} / \mathrm{w}): 0.5- \\
5\end{array}$ \\
\hline Solvents & 3 & 20 & $8,6,6$ & 1.68179 & $\begin{array}{l}T\left({ }^{\circ} \mathrm{C}\right): 100-200 \\
\mathrm{t}(\mathrm{min}): 5-120 \\
\text { Solvent }(\%, \quad \mathrm{w} / \mathrm{w}) \\
10-70\end{array}$ \\
\hline Surfactants & 3 & 20 & $8,6,6$ & 1.68179 & $\begin{array}{l}\mathrm{T}\left({ }^{\circ} \mathrm{C}\right): 100-200 \\
\mathrm{t}(\mathrm{min}): 5-120 \\
\text { Surfactant }(\%, \mathrm{w} / \mathrm{w}) \\
0.3-5.7\end{array}$ \\
\hline
\end{tabular}

After the thermal pretreatment, an enzymatic hydrolysis was performed on the biomass solid/liquid mixture obtained in the reactor. For technical reasons, only one fourth part 
of this mixture was used (i.e. about $100 \mathrm{~g}$ ), paying special care to keeping the proportion of solids and liquid hydrolysates. Each sample was placed in a 500-mL Erlenmeyer flask, and then a $5-\mathrm{mL}$ solution containing $0.97 \mathrm{~g}$ citric acid was added. The $\mathrm{pH}$ was adjusted to 5.0 with a concentrated $\mathrm{NaOH}$ or $\mathrm{HCl}$ solution. This made a buffer citrate of about $50 \mathrm{mM}$ and $\mathrm{pH} 5.0$. Afterwards, $290 \mu \mathrm{l}$ of the enzyme Cellic CTec 2 were added. The flasks were capped and placed in an orbital shaker at $50{ }^{\circ} \mathrm{C}$ and 180 rpm during $72 \mathrm{~h}$. In the case of samples treated with organic solvents, two different strategies were used: a) the samples were processed as explained before, and this experiment was identified as "slurry", and b) the solid biomass was separated from the liquid by filtration after the reactor pretreatment, and that liquid was substituted by an equivalent amount of water to perform the subsequent enzymatic hydrolysis, and this experiment was identified as "water". This was done to reduce the presence of organic solvents in the final broth, which might hinder bacterial fermentation. The $\mathrm{pH}$ adjustment, enzyme addition and enzymatic hydrolysis conditions were the same as those described previously. After the enzymatic hydrolysis, all the samples were filtered, centrifuged and prepared for chemical analyses as explained in the previous subsection. Simple sugars as well as potential fermentation inhibitors were analysed.

In the case of autohydrolysis experiments, two variables were optimized regarding the pretreatment in the reactor: temperature and time. In the case of acidic, alkaline, organic solvent or surfactant treatments, three variables were optimized: temperature, time and reagent amount. In order to perform the optimization, complete central design (CCD) and response surface methodology (RSM) experiments were performed for each pretreatment type. The enzymatic hydrolysis process was the same for all the samples. Some characteristics of these RSM experiments can be found in Table 2. A response surface was calculated and the resulting equations were used to estimate the optimal temperature, time and reagent concentration values to obtain the highest amount of total sugars released and the lowest amount of total inhibitors in the broth after the physicochemical treatment in the reactor and the subsequent enzymatic hydrolysis. Total inhibitors were calculated as the sum of formic acid, acetic acid, levulinic acid, furfural, 5-hydroxymethylfurfural (5-HMF) and total phenolic compounds concentrations. Afterwards, all the mathematically estimated optimal points were validated with experiments.

\section{Fermentation of the liquid hydrolysates from the pretreatment}

Strain culture was performed according to Díez-Antolínez et al. (2016). In brief, the strain Clostridium beijerinckii CECT 508 (NCIMB 8052) was obtained from the Spanish Collection of Type Strains (CECT, Paterna, Spain). The lyophilised cells were resuspended in synthetic medium consisting of $19 \mathrm{~g} / \mathrm{L}$ Reinforced Clostridial Medium (Oxoid, Basingstoke, UK) and $10 \mathrm{~g} / \mathrm{L}$ lactose (Sigma-Aldrich, Steinheim, Germany) and exposed to a thermal shock $\left(2 \mathrm{~min}\right.$ at $80^{\circ} \mathrm{C}$ in a water bath and $5 \mathrm{~min}$ in ice). They were subjected to sporulation according to the CECT protocol. Then, $500 \mu \mathrm{l}$ spores were added to $100 \mathrm{~mL}$ of the above-mentioned synthetic medium, which was placed in glass bottles capped with a rubber septum, and exposed to a thermal shock. Afterwards, gaseous $\mathrm{N}_{2}$ was bubbled into the headspace of the closed bottles during 5 min to obtain anaerobic conditions. The bottles were incubated for $20 \mathrm{~h}$ at $35{ }^{\circ} \mathrm{C}$ and were employed as inocula, containing an approximate bacterial density of $6 \cdot 10^{8}$ cells $/ \mathrm{mL}$. For fermentability tests, after filtration and centrifugation, hydrolysates were supplemented

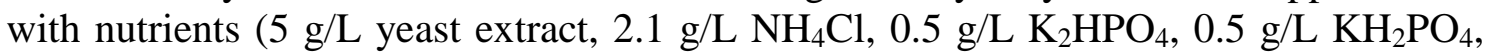


$0.01 \mathrm{~g} / \mathrm{L} \mathrm{FeSO}_{4} \cdot 7 \mathrm{H}_{2} \mathrm{O}, 0.2 \mathrm{~g} / \mathrm{L} \mathrm{MgSO}_{4} \cdot 7 \mathrm{H}_{2} \mathrm{O}$, and $0.5 \mathrm{~g} / \mathrm{L}$ cysteine) and $5 \mathrm{~g} / \mathrm{L} \mathrm{CaCO}_{3}$ for $\mathrm{pH}$ control. All these compounds were autoclaved within the fermentation medium, except cysteine and iron and magnesium salts, which were added as a microfiltered concentrated solution after autoclaving. The initial $\mathrm{pH}$ was adjusted to 6.00 with $\mathrm{NaOH}$. Then, $1.5 \mathrm{~mL}$ of inoculum were added to $48.5 \mathrm{~mL}$ of fermentation medium in rubbercapped bottles. Gaseous $\mathrm{N}_{2}$ was bubbled into the bottom of the closed bottles during 5 min to guarantee anaerobic conditions. Fermentation bottles were incubated at $35^{\circ} \mathrm{C}$ and $100 \mathrm{rpm}$ in an Infors HT Minitron orbital shaker (Infors AG, Bottmingen, Switzerland) during 96 h.. These experiments were performed in triplicate. Fermentation controls were prepared with aqueous solutions containing glucose and xylose mixtures at similar concentrations to those of the apple pomace hydrolysates, and supplemented with the abovementioned nutrients and salts.

\section{Chemical analyses}

Aqueous samples were centrifuged at $13,000 \mathrm{rpm}$ in a microcentrifuge for $3 \mathrm{~min}$ (Minispin, Eppendorf, Hamburg, Germany). The supernatant was filtered through a nylon syringe filter $(0.20 \mu \mathrm{m}$ pore; Agilent, Santa Clara, CA, USA) prior to analysis. The sugars cellobiose, glucose, xylose, rhamnose and arabinose, and the potential inhibitors formic acid, acetic acid, levulinic acid, 5-hydroxymethylfurfural (5-HMF) and furfural were analysed by HPLC with an Agilent 1200 HPLC equipment (Agilent Technologies) provided with a 300 x $7.8 \mathrm{~mm}$ i.d. cation exchange column Aminex HPX-87H (Biorad, Hercules, CA, USA) and a Refractive Index Detector (RID) G1362A (Agilent Technologies). The mobile phase was $5 \mathrm{mM} \mathrm{H}_{2} \mathrm{SO}_{4}$ at a flow rate of $0.6 \mathrm{~mL} / \mathrm{min}$. The column temperature was set at $60^{\circ} \mathrm{C}$. The injection volume was 20 $\mu L$. In this HPLC analytical method, galactose and mannose are quantified together with xylose; whereas maltose is quantified together with cellobiose. Other inhibitors, like phenolic compounds, were analysed by Folin-Denis' assay. Total phenolic compounds were expressed as gallic acid equivalents (GAE).

Fermentation metabolites, like acetone, butanol, ethanol, acetic acid and butyric acid were determined by GC using an Agilent 7890 GC equipped with a flame ionization detector (FID) and provided with a HP Innowax $30 \mathrm{~m} \times 0.530 \mathrm{~mm}, 1.00 \mu \mathrm{m}$ column (Agilent Technologies, Santa Clara, CA, USA). The FID flame was maintained with a mixture of $30 \mathrm{~mL} / \mathrm{min} \mathrm{H}_{2}$ and $400 \mathrm{~mL} / \mathrm{min}$ air, using $\mathrm{N}_{2}$ as make-up gas. An aqueous sample of $1 \mu \mathrm{l}$ was injected in split mode (split ratio 25) at a temperature of $250{ }^{\circ} \mathrm{C}$. The oven temperature was set at $40{ }^{\circ} \mathrm{C}$ during $2 \mathrm{~min}$, then raised to $45{ }^{\circ} \mathrm{C}$ at a rate of 5 ${ }^{\circ} \mathrm{C} / \mathrm{min}$ and finally raised to $225^{\circ} \mathrm{C}$ at a rate of $20^{\circ} \mathrm{C} / \mathrm{min}$. The detector temperature was set at $250{ }^{\circ} \mathrm{C}$. Helium at $2 \mathrm{~mL} / \mathrm{min}$ was used as the carrier gas. Fermentation yields $\left(\mathrm{Y}_{\mathrm{i} / \mathrm{S}}\right.$, $\mathrm{g} / \mathrm{g}$ ) were calculated as the ratio between the metabolite (i) produced and the total sugars consumed (S). Metabolite productivity rates $\left(\mathrm{W}_{\mathrm{i}}, \mathrm{g} /(\mathrm{L} \cdot \mathrm{h})\right)$ were calculated as the ratio between the metabolite (i) expressed in concentration $(\mathrm{g} / \mathrm{L})$ and the fermentation time (h). Sugar recovery or sugar conversion efficiency (\%) was calculated as the ratio between the amount of simple sugars in the hydrolysate and the total amount of carbohydrates in the untreated apple pomace.

\section{$\underline{\text { Statistical analyses }}$}

Comparisons among treatments were assessed with one-way ANOVA and the Tukey HSD test using the software Statistica 7 (StatSoft Inc., Tulsa, OK, USA); differences 
were considered significant when $\mathrm{p}<0.05$. For the optimisation step, experimental designs, such as Response Surface Methodology (RSM) were generated and interpreted with the software Minitab 16 (Minitab Inc., State College, PA, USA). Bar graphs were created with the software SigmaPlot v.11 (Systat Software Inc., San Jose, CA, USA).

\section{Results}

\section{Preliminary selection of suitable chemical compounds for the pretreatment}

The preliminary comparison tests were used to select one reagent of each group to perform the pretreatment optimization in the high-pressure reactor. The most suitable reagent in each case was selected according to the Tukey HSD statistical test, by prioritizing high concentrations of total released sugars and low concentrations of total inhibitors (Table 3). The highest sugar concentrations were provided by acidic pretreatments $(44-53 \mathrm{~g} / \mathrm{L})$, followed by surfactants and organic solvents $(31-37 \mathrm{~g} / \mathrm{L})$. Regarding dilute acid pretreatments, nitric acid was significantly more efficient than the other compounds (Table 3). Alkalis yielded much lower sugar concentrations than the other reagent groups (17-19 g/L), an amount which was considered insufficient for ABE fermentation. Therefore, the use of alkalis in the subsequent RSM optimisation step was excluded, because it did not seem appropriate for apple pomace. The three tested organic solvents offered similar results; but acetone was finally chosen due to its lower price and toxicity in comparison to ethanol and methanol. In the case of surfactants, there were no significant differences between PEG 6000 and CTAB, but the former offered less variable results.

Regarding total inhibitors (calculated as a sum of formic, acetic and levulinic acids, furfural, 5-HMF and phenolic compounds), acid pretreatments generated the highest quantity, followed by surfactant- and organic solvent-pretreatments (Table 3).

Table 3. Reagents selected for apple pomace in the preliminary autoclave tests. Note: Superscripts $(a, b)$ represent statistical differences among treatments $(p<0.05)$. For a certain treatment type (e.g. acids), two reagents with distinct letters differ significantly.

\begin{tabular}{|l|l|l|l|l|}
\hline Treatment type & Reagent & Total sugars (g/L) & Total inhibitors (g/L) & Selected reagent \\
\hline Autohydrolysis & - & - & - & - \\
\hline \multirow{4}{*}{ Acid } & $\mathrm{H}_{2} \mathrm{SO}_{4}$ & $44.0 \pm 0.33^{\mathrm{a}}$ & $8.96 \pm 0.11^{\mathrm{a}}$ & \multirow{2}{*}{$\mathrm{HNO}_{3}$} \\
\cline { 2 - 4 } & $\mathrm{HCl}$ & $44.5 \pm 0.31^{\mathrm{a}}$ & $9.16 \pm 0.05^{\mathrm{a}}$ & \\
\cline { 2 - 4 } & $\mathrm{HNO}$ & $53.1 \pm 1.16^{\mathrm{b}}$ & $4.05 \pm 0.08^{\mathrm{b}}$ & \\
\hline \multirow{4}{*}{ Alkali } & $\mathrm{NaOH}$ & $19.1 \pm 0.63^{\mathrm{a}}$ & $8.06 \pm 0.13^{\mathrm{a}}$ & \multirow{3}{*}{ Not efficient } \\
\cline { 2 - 4 } & $\mathrm{KOH}$ & $18.8 \pm 3.10^{\mathrm{a}}$ & $6.86 \pm 0.53^{\mathrm{b}}$ & \\
\cline { 2 - 4 } & $\mathrm{NH}_{4} \mathrm{OH}$ & $17.4 \pm 0.24^{\mathrm{a}}$ & $3.96 \pm 0.04^{\mathrm{c}}$ & \\
\hline \multirow{4}{*}{ Organic solvent } & Ethanol & $33.0 \pm 0.44^{\mathrm{a}}$ & $0.97 \pm 0.07^{\mathrm{a}}$ & \multirow{3}{*}{ Acetone } \\
\cline { 2 - 4 } & Methanol & $31.4 \pm 1.63^{\mathrm{a}}$ & $1.03 \pm 0.09^{\mathrm{a}}$ & \\
\cline { 2 - 4 } & Acetone & $33.4 \pm 0.30^{\mathrm{a}}$ & $0.92 \pm 0.04^{\mathrm{a}}$ & \\
& Tween 80 & $32.4 \pm 2.13^{\mathrm{a}}$ & $4.42 \pm 0.15^{\mathrm{a}}$ & \multirow{2}{*}{ PEG 6000} \\
\cline { 2 - 4 } & $\mathrm{PEG} 6000$ & $36.8 \pm 0.98^{\mathrm{a}}$ & $1.07 \pm 0.05^{\mathrm{b}}$ & \\
\cline { 2 - 4 } & $\mathrm{CTAB}$ & $30.7 \pm 4.67^{\mathrm{a}}$ & $1.23 \pm 0.14^{\mathrm{b}}$ & \\
\hline
\end{tabular}

According to the results (Table 3), $\mathrm{HNO}_{3}$, acetone and PEG 6000 were chosen as the most adequate reagents within their groups (acids, organic solvents and surfactants, respectively). Their optimal working conditions were established via RSM, together with those of autohydrolysis (see next subsection). 


\section{Optimisation of pretreatment conditions}

Optimal working conditions in the reactor (temperature, time and amount of reagent) were calculated via RSM experimental design for autohydrolysis, nitric acid, acetone and PEG 6000 pretreatments. Table 4 shows the suggested values for each parameter and pretreatment. The lowest operational temperature was obtained for surfactant hydrolysis $\left(100^{\circ} \mathrm{C}\right)$, whereas the highest one was recorded for autohydrolysis $\left(142^{\circ} \mathrm{C}\right)$. Treatment times were remarkably short for all the pretreatments (below $12 \mathrm{~min}$ ), and the amount of reagents needed to perform an efficient hydrolysis was always relatively low (Table 4), which makes the treatments economic and environmentally-friendly.

The theoretical values estimated for total sugars and total inhibitors were validated experimentally (Table 4). Some small differences were observed between estimated and experimental values (especially in the cases of nitric acid and PEG 6000), but in general the models were acceptable. It must be remembered that enzymatic hydrolysis in the case of "Acetone (water)" was slightly different, since it was performed on the filtered solid biomass coming out the reactor (in order to remove acetone, which could be harmful to ABE fermentation). However, the optimal working conditions for acetone were also checked performing the enzymatic hydrolysis on the whole pretreatment slurry [Acetone (slurry)]; thus obtaining more sugars than estimated by the model, mainly because the xylose released during the pretreatment in the reactor was conserved in the slurry which was further subjected to the enzymatic step.

Table 4. Optimal working conditions, estimated responses (calculated with RSM) and validation experimental responses for apple pomace in the high-pressure reactor for each pretreatment method. Note: Enzymatic hydrolysis was performed on the whole pretreatment slurry for all the samples except "Acetone (water)".

\begin{tabular}{|l|c|c|c|c|c|c|c|}
\hline & \multicolumn{2}{|c|}{$\begin{array}{c}\text { Physicochemical treatment } \\
\text { optimal conditions (RSM) }\end{array}$} & \multicolumn{2}{c|}{$\begin{array}{c}\text { Estimated responses } \\
(\mathrm{RSM})\end{array}$} & \multicolumn{2}{c|}{ Experimental responses } \\
\hline & $\mathrm{T}\left({ }^{\circ} \mathrm{C}\right)$ & $\mathrm{t}(\mathrm{min})$ & $\begin{array}{c}\text { Reagent } \\
(\%, \mathrm{w} / \mathrm{w})\end{array}$ & $\begin{array}{c}\text { Total } \\
\text { sugars } \\
(\mathrm{g} / \mathrm{L})\end{array}$ & $\begin{array}{c}\text { Total } \\
\text { inhibitors } \\
(\mathrm{g} / \mathrm{L})\end{array}$ & $\begin{array}{c}\text { Total } \\
\text { sugars } \\
(\mathrm{g} / \mathrm{L})\end{array}$ & $\begin{array}{c}\text { Total } \\
\text { inhibitors } \\
(\mathrm{g} / \mathrm{L})\end{array}$ \\
\hline Autohydrolysis & 142.4 & 12.0 & - & 40.6 & 0.97 & $42.7 \pm 0.53$ & $1.30 \pm 0.38$ \\
\hline $\mathrm{HNO}_{3}$ & 124.2 & 7.3 & 1.83 & 49.2 & 1.99 & $51.8 \pm 1.17$ & $2.97 \pm 0.02$ \\
\hline Acetone (water) & 112.1 & 5.0 & 10 & 32.6 & 0.64 & $27.3 \pm 0.06$ & $0.55 \pm 0.06$ \\
\hline Acetone (slurry) & 112.1 & 5.0 & 10 & - & - & $40.6 \pm 3.16$ & $0.72 \pm 0.06$ \\
\hline PEG 6000 & 100.2 & 5.0 & 1.96 & 46.0 & 0.0 & $42.0 \pm 0.46$ & $0.80 \pm 0.17$ \\
\hline
\end{tabular}

The most efficient pretreatment in terms of total sugar release was nitric acid hydrolysis (51.8 g/L), whereas all the other treatments offered values about 40-43 g/L (Fig. 1a), except obviously the "Acetone (water)" sample (27.3 g/L sugars). The main simple sugars obtained from apple pomace hydrolysis were glucose and xylose, whereas cellobiose, rhamnose and arabinose were present at low concentrations (Fig. 1a). Considering the carbohydrate composition of apple pomace $(55.86 \%$; Table 1$)$ and the hydrolysate volumes collected, sugar recovery performances ranged between $38 \%$ for the less efficient acetone treatment and $76 \%$ for nitric acid (Fig. 1b).

The concentration of inhibitors generated by nitric acid was the highest (Fig. 1c), especially for formic acid $(0.57 \mathrm{~g} / \mathrm{L})$ and acetic acid $(1.49 \mathrm{~g} / \mathrm{L})$. Autohydrolysis and nitric acid caused the appearance of relevant concentrations of phenolic compounds $(0.67 \mathrm{~g} / \mathrm{L})$. On the contrary, PEG 6000 and acetone produced hydrolysates with low 
inhibitor concentrations $(<0.80 \mathrm{~g} / \mathrm{L}$ total inhibitors $)$, especially in the case of "Acetone (water)".
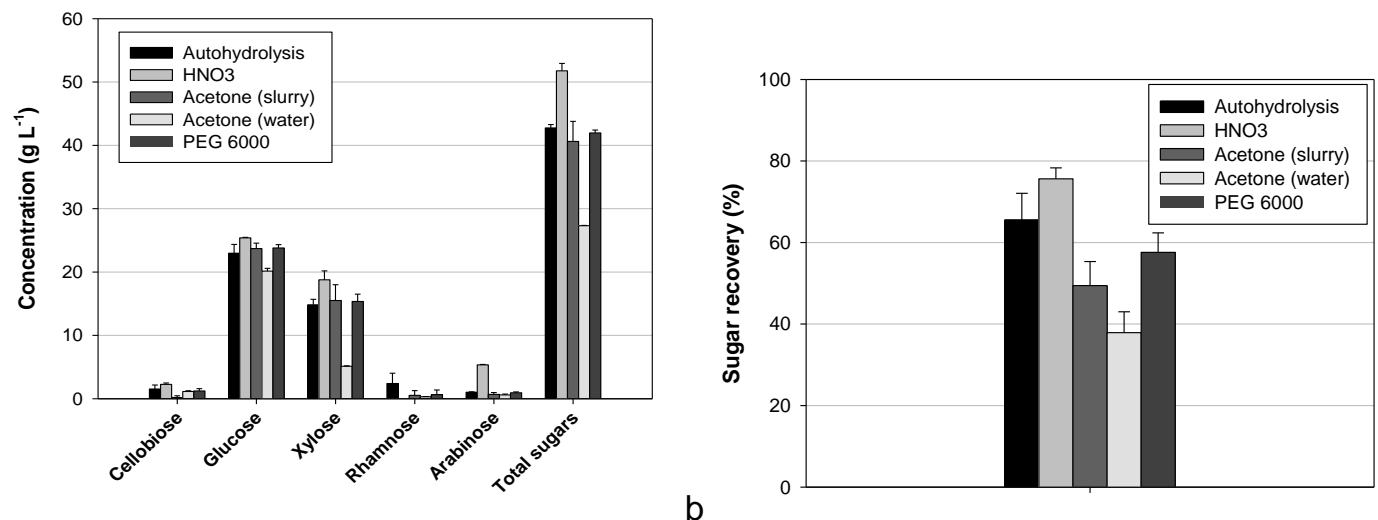

a

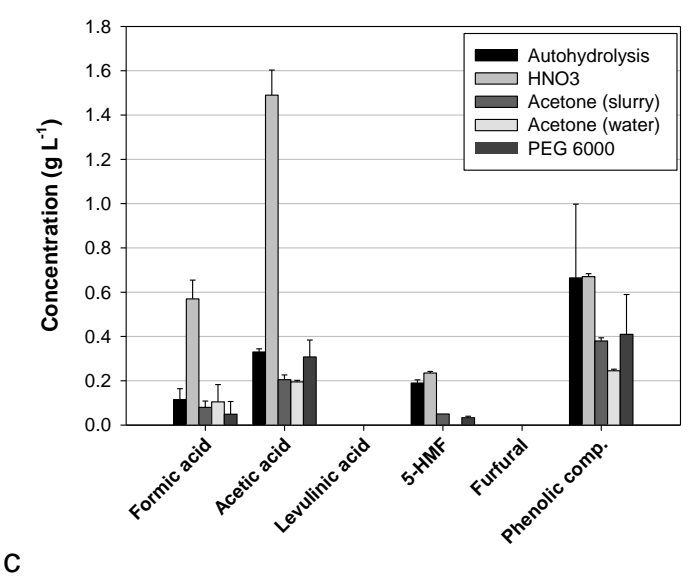

Fig. 1 Composition of apple pomace hydrolysates for each pretreatment under optimal conditions. a) Concentration of released sugars. b) Sugar recovery. c) Concentration of inhibitors generated. Note: Galactose and mannose were quantified together with xylose; and maltose was quantified together with cellobiose

\section{Fermentability}

All the hydrolysates tested were fermentable, except that of nitric acid (Table 5). This could be due to the highest content of inhibitors generated in the acidic treatment, especially formic acid (Fig. 1c). The greatest butanol concentrations were obtained in the hydrolysates coming from the autohydrolysis $(6.27 \mathrm{~g} / \mathrm{L})$ and the PEG 6000 surfactant-pretreatment $(9.11 \mathrm{~g} / \mathrm{L})$. In fact, the results observed for the PEG 6000 hydrolysate were better than those recorded for its respective control (Table 5), reaching $91 \%$ sugar consumption with a butanol yield of $0.28 \mathrm{~g} / \mathrm{g}$ and a productivity of 0.095 $\mathrm{g} /(\mathrm{L} \cdot \mathrm{h})$. This implies that all the inhibitors present in this hydrolysate were below toxicity levels for this bacterial strain. 
Table 5. Sugar consumption and ABE parameters for a 96-h fermentation of apple pomace hydrolysates by $C$. beijerinckii CECT 508. $\left({ }^{*}\right)$ Total sugars include cellobiose, glucose, xylose, rhamnose and arabinose.

\begin{tabular}{|c|c|c|c|c|c|c|c|c|c|c|c|}
\hline \multirow[b]{2}{*}{ Treatment } & \multirow[b]{2}{*}{ Sample } & \multicolumn{3}{|c|}{ Sugar consumption (\%) } & \multicolumn{5}{|c|}{ ABE metabolites $(g / L)$} & \multirow{2}{*}{$\begin{array}{c}\text { Yield } \\
Y_{B}(g / g)\end{array}$} & \multirow{2}{*}{$\begin{array}{l}\text { Productivity } \\
W_{B}(g / L \cdot h)\end{array}$} \\
\hline & & Glucose & Xylose & Total sugars* & Acetone & Butanol & Ethanol & Acetic acid & Butyric acid & & \\
\hline \multirow{2}{*}{ Autohydrolysis } & Control & 100 & 84 & 94 & 1.98 & 8.26 & 0.15 & 0.53 & 0.56 & 0.21 & 0.086 \\
\hline & Apple pomace & $97 \pm 4$ & $96 \pm 1$ & $91 \pm 3$ & $1.85 \pm 0.41$ & $6.27 \pm 1.04$ & $0.20 \pm 0.02$ & $3.93 \pm 0.39$ & $3.95 \pm 0.43$ & $0.17 \pm 0.02$ & $0.065 \pm 0.011$ \\
\hline \multirow{2}{*}{$\mathrm{HNO}_{3}$} & Control & 81 & 73 & 77 & 2.60 & 9.80 & 0.16 & 1.20 & 0.80 & 0.23 & 0.102 \\
\hline & Apple pomace & $3 \pm 2$ & $13 \pm 10$ & $6 \pm 1$ & 0 & $0.11 \pm 0.03$ & 0 & $1.58 \pm 0.14$ & $1.27 \pm 1.47$ & $0.03 \pm 0.00$ & $0.001 \pm 0.000$ \\
\hline \multirow{2}{*}{ Acetone (slurry) } & Control & 100 & 91 & 96 & 1.73 & 6.94 & 0.12 & 1.14 & 1.79 & 0.19 & 0.072 \\
\hline & Apple pomace & $98 \pm 2$ & $90 \pm 6$ & $92 \pm 2$ & $4.96 \pm 0.86$ & $5.70 \pm 2.33$ & $4.47 \pm 4.08$ & $3.09 \pm 1.10$ & $1.17 \pm 0.11$ & $0.16 \pm 0.07$ & $0.059 \pm 0.024$ \\
\hline \multirow{2}{*}{ Acetone (water) } & Control & 100 & 99 & 99 & 0.76 & 4.06 & 0.1 & 1.27 & 2.07 & 0.15 & 0.042 \\
\hline & Apple pomace & $98 \pm 1$ & $91 \pm 0$ & $96 \pm 1$ & $8.58 \pm 0.24$ & $5.05 \pm 0.16$ & $0.20 \pm 0.01$ & $2.35 \pm 0.01$ & $0.85 \pm 0.06$ & $0.19 \pm 0.01$ & $0.053 \pm 0.002$ \\
\hline \multirow{2}{*}{ PEG 6000} & Control & 95 & 79 & 88 & 1.83 & 8.72 & 0.14 & 0.88 & 0.74 & 0.24 & 0.091 \\
\hline & Apple pomace & $99 \pm 0$ & $94 \pm 0$ & $91 \pm 0$ & $3.55 \pm 0$ & $9.11 \pm 0.21$ & $0.26 \pm 0.00$ & $1.80 \pm 0.13$ & $0.82 \pm 0.04$ & $0.28 \pm 0.01$ & $0.095 \pm 0.002$ \\
\hline
\end{tabular}

Table 6. Enthalpy values and their associated temperatures for solid biomass samples. Notes: R: after physicochemical treatment in the reactor, E: after enzymatic hydrolysis.

\begin{tabular}{|c|c|c|c|c|c|c|c|c|c|c|c|}
\hline \multirow[b]{2}{*}{ Pretreatment } & \multirow[b]{2}{*}{ Stage } & \multicolumn{2}{|l|}{ Peak 1} & \multicolumn{2}{|l|}{ Peak 2} & \multicolumn{2}{|c|}{ Peak 3} & \multicolumn{2}{|l|}{ Peak 4} & \multicolumn{2}{|l|}{ Peak 5} \\
\hline & & $\mathrm{T}\left({ }^{\circ} \mathrm{C}\right)$ & Enthalpy $(\mathrm{J} / \mathrm{g})$ & $\mathrm{T}\left({ }^{\circ} \mathrm{C}\right)$ & Enthalpy $(\mathrm{J} / \mathrm{g})$ & $\mathrm{T}\left({ }^{\circ} \mathrm{C}\right)$ & Enthalpy $(\mathrm{J} / \mathrm{g})$ & $\mathrm{T}\left({ }^{\circ} \mathrm{C}\right)$ & Enthalpy $(\mathrm{J} / \mathrm{g})$ & $\mathrm{T}\left({ }^{\circ} \mathrm{C}\right)$ & Enthalpy $(\mathrm{J} / \mathrm{g})$ \\
\hline None (apple pomace) & - & 183 & -380.2 & - & - & 356 & 27.9 & - & - & - & - \\
\hline \multirow{2}{*}{ Autohydrolysis } & $\mathrm{R}$ & 101 & -421.8 & - & - & 360 & 30.3 & 432 & 10.0 & - & - \\
\hline & $E$ & 105 & -208.3 & - & - & 349 & 10.4 & 403 & 2.3 & - & - \\
\hline \multirow{2}{*}{ Nitric acid } & $\mathrm{R}$ & 144 & 36.8 & 252 & 5.5 & 357 & 48.1 & - & - & - & - \\
\hline & $E$ & 102 & -206.9 & 242 & 1.1 & 329 & 57.1 & 395 & 3.2 & 444 & 3.1 \\
\hline \multirow{2}{*}{ Acetone (slurry) } & $\mathrm{R}$ & 142 & -296.8 & - & - & 360 & 30.1 & - & - & - & - \\
\hline & $E$ & 106 & -215.1 & 286 & 4.2 & 347 & 18.3 & 417 & 9.1 & - & - \\
\hline \multirow{2}{*}{ Acetone (water) } & $\mathrm{R}$ & 142 & -296.8 & - & - & 360 & 30.1 & - & - & - & - \\
\hline & $E$ & 105 & -177.1 & 295 & 3.1 & 349 & 21.0 & 421 & 11.1 & - & - \\
\hline \multirow{2}{*}{ PEG 6000} & $\mathrm{R}$ & 123 & -321.9 & 310 & 1.7 & 361 & 13.7 & 417 & 8.5 & - & - \\
\hline & $E$ & 114 & -165.1 & 290 & 6.8 & 349 & 13.3 & 414 & 35.8 & - & - \\
\hline
\end{tabular}


It must be highlighted that the two samples obtained with the acetone treatments were fermentable, in spite of the relatively high initial concentrations of this solvent in the broth, which were $38.57 \mathrm{~g} / \mathrm{L}$ for "Acetone (slurry)" and $14.45 \mathrm{~g} / \mathrm{L}$ for "Acetone (water)". In the case of the "Acetone (water)" sample, the solid biomass was not washed after filtration, so it still contained some acetone absorbed. This sample attained a butanol concentration of $5.05 \mathrm{~g} / \mathrm{L}$ after the fermentation, despite its apparently low sugar initial concentration $(27.3 \mathrm{~g} / \mathrm{L})$. Another remarkable phenomenon was the decrease of acetone concentration in these two samples after fermentation (Table 5). It was checked that the employed strain was not able to convert acetone into isopropanol (in a control with an initial concentration of $20 \mathrm{~g} / \mathrm{l}$ acetone, only $0.14 \mathrm{~g} / \mathrm{l}$ isopropanol were produced, and acetone concentration did not diminish); therefore, this reduction could be hypothetically due to evaporation, adsorption onto suspended solids, degradation or an unknown metabolic pathway in the complex hydrolysate matrix.

\section{Thermal analysis}

The effect of the different pretreatments on apple pomace is reflected on the thermal behaviour of the resultant biomass. Enthalpy changes during the heating of the samples are shown in Fig. 2. Enthalpy values and their associated temperatures are given in Table 6.

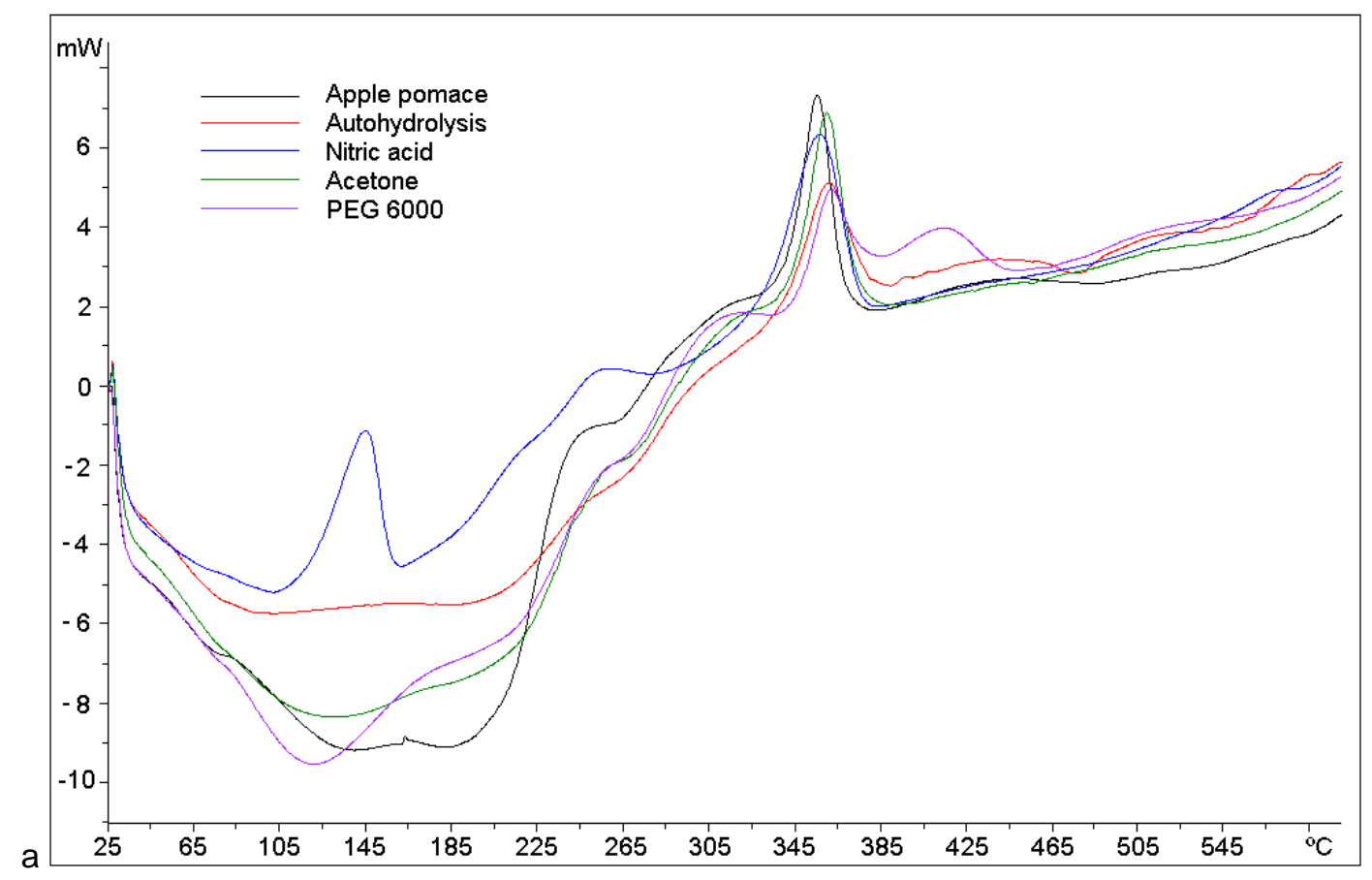




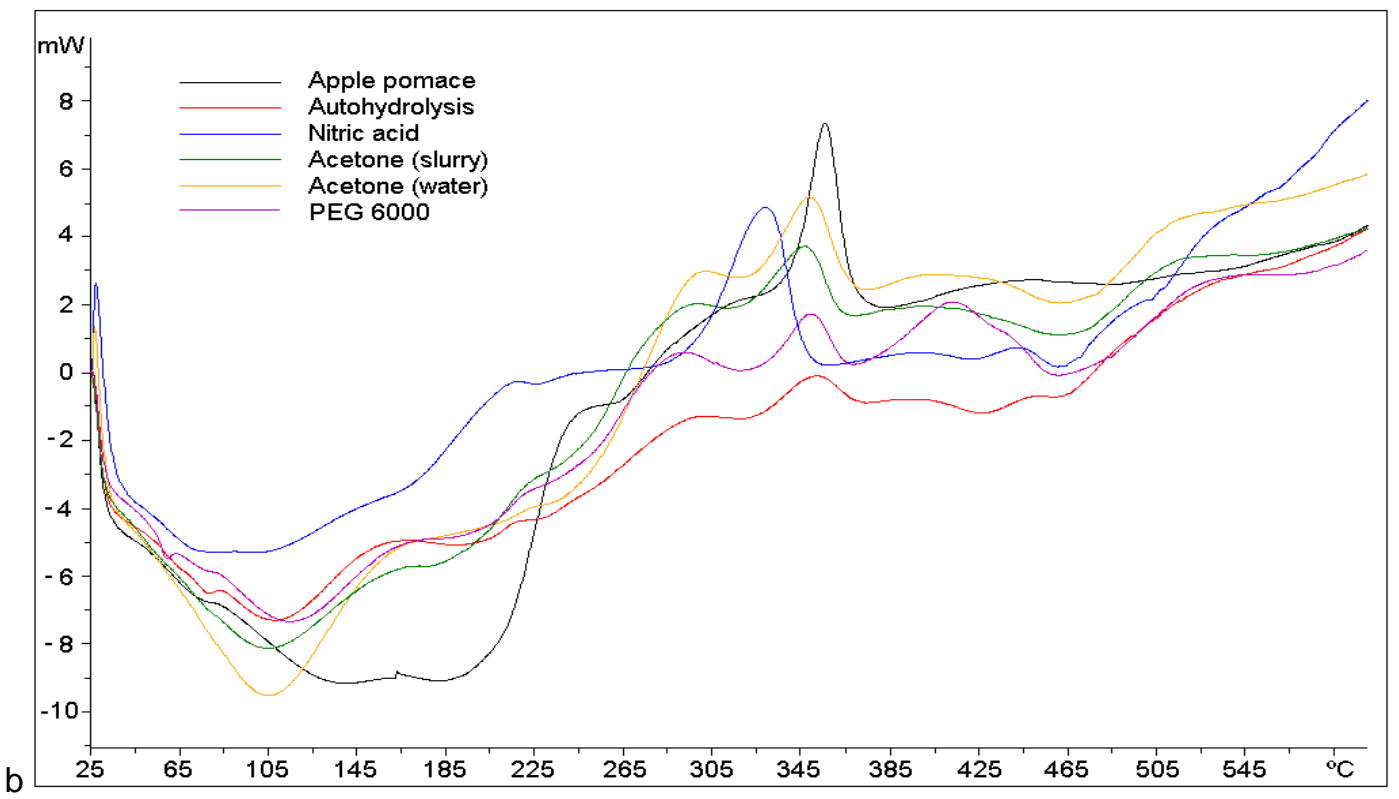

Fig. 2 Diagrams of the differential scanning calorimetry (DSC) of solid biomass. a) Samples after physicochemical pretreatments in the reactor. b) Samples after the sequential physicochemical and enzymatic hydrolyses. Note: The curve of the untreated apple pomace is shown in both diagrams as a reference

The untreated apple pomace showed a broad endothermic peak below $240{ }^{\circ} \mathrm{C}$, followed by a small exothermic shoulder and a sharp exothermic peak at $356{ }^{\circ} \mathrm{C}$. The physicochemical treatments in the reactor resulted in some modifications in the DSC curves (Fig. 2a). In general, all the treated samples were characterized by an exothermic peak at about $355-360{ }^{\circ} \mathrm{C}$, although in the case of the PEG 6000-pretreatment its specific enthalpy was slightly lower than that of the untreated biomass (Fig. 2a, Table 6). These data indicate that lignin is still present after physicochemical pretreatments in the reactor. Moreover, the PEG 6000 treatment caused the appearance of a new exothermic peak at about $415^{\circ} \mathrm{C}$ (which does not seem to coincide with the pyrolysis of pure PEG 6000, Fig. 3). In addition, autohydrolysis and especially nitric acid hydrolysis altered the curve shape in the temperature range below $240{ }^{\circ} \mathrm{C}$, obtaining less endothermic results. All the phenomena registered above $290{ }^{\circ} \mathrm{C}$ were exothermic, both for untreated and treated samples. 


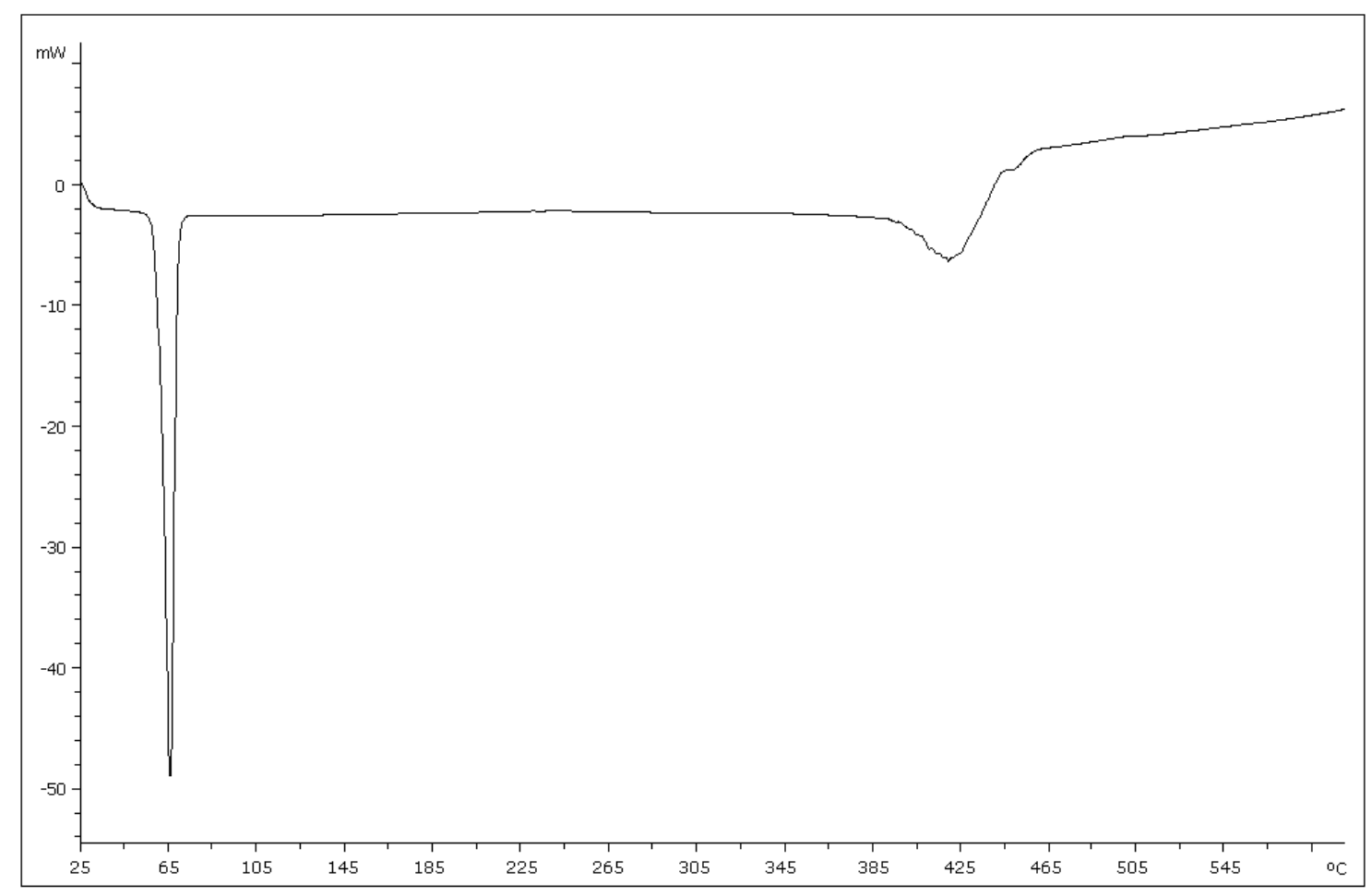

Fig. 3. Diagram of the differential scanning calorimetry (DSC) of PEG 6000.

The samples coming out the reactor were subjected to a common enzymatic hydrolysis. Their thermal analysis offered DSC curves with softer and rounder peaks (Fig. 2b). Once more, treated samples showed a well-defined exothermic peak at $330-350{ }^{\circ} \mathrm{C}$, with a shift towards lower temperatures in comparison to the untreated sample $\left(356^{\circ} \mathrm{C}\right)$; a fact which was more evident for the nitric acid hydrolysate. The enthalpies of this peak had diminished in comparison to the previous pretreatment stage (Table 2). This decrease might indicate the degradation of lignin during the enzymatic pretreatment. The only exception was nitric acid, whose lignin peak showed an area increase. Again, the sample treated with PEG 6000 exhibited an exothermic peak at about $415^{\circ} \mathrm{C}$ (Fig. $2 b)$. It must be pointed out that the autohydrolysis curve showed negative (i.e. endothermic) values until a temperature of $480^{\circ} \mathrm{C}$ was attained (Fig. 2b), a phenomenon whose interpretation would need a deeper study.

\section{Discussion}

\section{Biomass pretreatment}

Preliminary tests suggested that $\mathrm{HNO}_{3}$ (acid), acetone (organic solvent) and PEG 6000 (surfactant) were the most adequate reagents within their groups for apple pomace pretreatment (Table 3). Nevertheless, sulfuric acid is the most commonly reported acid in scientific literature (Lloyd and Wyman 2005; Ezeji et al. 2007; Qureshi et al. 2010). The most frequent organic solvents employed in biomass pretreatment are acetone (Araque et al. 2008) and especially ethanol (Kurabi et al. 2005; Mesa et al. 2011).

As shown in Table 4, operational temperatures ranged between $100{ }^{\circ} \mathrm{C}$ for surfactant hydrolysis and $142{ }^{\circ} \mathrm{C}$ for autohydrolysis. Conventional autohydrolysis temperatures are above $170{ }^{\circ} \mathrm{C}$ (Lee et al. 2009; Buruiana et al. 2014; Gonçalves et al. 2015), and acid-, 
organosolv- and surfactant-mediated hydrolyses are usually performed at $135-195{ }^{\circ} \mathrm{C}$ (Mesa et al. 2011; Wei et al. 2011; Orozco et al. 2013). The short treatment times observed for apple pomace for all the pretreatments (Table 4) were in agreement with data provided in scientific literature (Araque et al. 2008; Orozco et al. 2013). The amount of reagents (1.83-10\%) employed to hydrolyse apple pomace (Table 4) was similar to data available in scientific literature. Previous works have reported reagent concentrations of $0.1-3 \%$ for acids like $\mathrm{H}_{2} \mathrm{SO}_{4}$ and $\mathrm{H}_{3} \mathrm{PO}_{4}$ (Jurgens et al. 2012; Orozco et al. 2013), 30-80\% for organic solvents (Araque et al. 2008; Mesa et al. 2011; Obama et al. 2012) and 0.2-1\% for surfactants combined with acids (Wei et al. 2011; Kapu et al. 2012;).

Sugar recovery efficiencies for apple pomace hydrolysis ranged between $38 \%$ and 76 $\%$ (Fig. 1b). These efficiency percentages are in accordance with previous works. For instance, Gama et al. (2015) tested the feasibility of enzymatic hydrolysis on an apple pomace containing $19.8 \%$ acid-insoluble lignin. Without pretreatment, the biomass was subjected to a hydrolysis with various enzymes and doses, obtaining a hydrolysate with $4.2 \mathrm{~g} / \mathrm{L}$ glucose and $16.8 \mathrm{~g} / \mathrm{L}$ reducing sugars under optimal conditions, which represents a sugar yield of $75 \%$. The experiments were performed with a biomass-tosolvent ratio of $20 \%$ d.w. ( $2 \%$ w.w.). However, the concentrations obtained by Gama et al. (2015) were considerably lower, since they did not apply a pretreatment and they worked with smaller biomass ratios.

\section{$\underline{\text { ABE fermentation of lignocellulosic apple pomace }}$}

As explained in the Results section, all the hydrolysates tested were fermentable, except that of nitric acid, and this could be related to inhibitor concentrations. It has been suggested that formic acid concentrations above 0.24-0.5 g/L can inhibit ABE fermentation (Zverlov et al. 2006; Sun et al. 2010), a threshold which was only surpassed by the acidic pretreatment in the present study. Inhibitor concentrations in the other hydrolysates (Fig. 1c) - especially in those treated by autohydrolysis and PEG 6000 , which were successfully fermented - were probably below toxicity levels for this bacterial strain. In fact, concentrations above $2.9 \mathrm{~g} / \mathrm{L}$ furfural (Zverlov et al. 2006), 3 $\mathrm{g} / \mathrm{L}$ 5-HMF (Zhang et al. 2012), $5 \mathrm{~g} / \mathrm{L}$ acetic acid (Kótai et al. 2013) and $1 \mathrm{~g} / \mathrm{L}$ total phenolic compounds (Cho et al. 2009) can be detrimental to solventogenic Clostridia. Even apple pomace samples treated by acetone hydrolysis were fermentable, in spite of their high initial concentration of this solvent. Kótai et al. (2013) have suggested that solventogenic Clostridium strains are able to tolerate high concentrations of acetone (above $29 \mathrm{~g} / \mathrm{L}$ ).

The ability to efficiently ferment glucose/xylose mixtures differs among bacterial strains. The employed strain was selected due to its capacity to deplete xylose even in the presence of glucose (Paniagua-García et al. in preparation). For instance, the PEG 6000 hydrolysate contained $23.8 \mathrm{~g} / \mathrm{L}$ glucose, $15.4 \mathrm{~g} / \mathrm{L}$ xylose, $1.2 \mathrm{~g} / \mathrm{L}$ cellobiose, 0.9 $\mathrm{g} / \mathrm{L}$ arabinose and $0.6 \mathrm{~g} / \mathrm{L}$ rhamnose, and during the fermentation most glucose and xylose were consumed (>93\%, Table 5). This proves that $C$. beijerinckii CECT 508 is a suitable microorganism for the fermentation of apple pomace. According to Kótai et al. (2013), the selection of raw material for ABE processes cannot be independent from the selection of the bacterial strain.

As mentioned in the Introduction, apple residues with high contents of free sugars have been assessed as fermentation feedstocks. Voget et al. (1985) used a wet apple pomace with high concentrations of free monosaccharides (10.8\%) and low fibre concentrations 
(4.5\%) to perform an ABE fermentation with Clostridium acetobutylicum NRRL B-596 and $C$. beijerinckii (NRRL B-592 and NRRL B-593), obtaining butanol concentrations of 8.35-9.45 g/L and yields of $0.22-0.26 \mathrm{~g} / \mathrm{g}$ from a broth with an initial sugar concentration of $43.2 \mathrm{~g} / \mathrm{L}$. Jesse et al. (2002) prepared a mixture of discarded apples, cracked corn, packing peanuts and water with a concentration of $96.4 \mathrm{~g} / \mathrm{L}$ fermentable sugars, and obtained $9.8 \mathrm{~g} / \mathrm{L}$ butanol with $C$. beijerinckii BA101. Maiti et al. (2016) obtained $1.4 \mathrm{~g} / \mathrm{L}$ butanol by fermenting an apple pomace ultra-filtration sludge with 30 $\mathrm{g} / \mathrm{L}$ reducing sugars with $C$. beijerinckii NRRL B-466 and they needed dilution and detoxification steps to reduce inhibitor concentrations. However, to the best of our knowledge, this is the first time that a lignocellulosic-rich apple waste (21\% cellulose, $15 \%$ hemicellulose, $18 \%$ lignin) is efficiently pretreated to obtain a directly fermentable hydrolysate which can produce acceptable butanol amounts without the need of detoxification.

In addition, these results confirm that enzymatic hydrolysis can be performed directly on the pretreatment slurry from the physicochemical reactor, containing solid biomass and liquid. This avoids the filtration step, contributes to water saving and preserves the xylose and other sugars released during hemicellulose degradation in the reactor, a strategy followed by several authors (Dien et al. 2006; Qureshi et al. 2010).

\section{Thermal analysis of apple pomace samples}

Regarding the untreated apple pomace biomass, which exhibited a broad endothermic peak below $240{ }^{\circ} \mathrm{C}$, followed by a small exothermic shoulder and a sharp exothermic peak at $356{ }^{\circ} \mathrm{C}$; it must be noted that the heating of lignocellulosic biomass is characterised by endothermic reactions below $100-167^{\circ} \mathrm{C}$, which are related to moisture evaporation and heating (He et al. 2006; Yang et al. 2007). The exothermic peak that appeared at $356{ }^{\circ} \mathrm{C}$ could correspond to lignin pyrolysis (Yang et al. 2007). The exothermic shoulder at about $275^{\circ} \mathrm{C}$ might be linked to hemicellulose pyrolysis (Yang et al. 2007).

The physicochemical treatments in the reactor resulted in some modifications in the DSC curves, and all of them showed an exothermic peak at about $355-360{ }^{\circ} \mathrm{C}$ probably linked to lignin (Fig. 2a). When these samples were subjected to a subsequent enzymatic hydrolysis, their DSC curves showed a shift towards lower temperatures in the lignin-related peak, and also lower enthalpies of this peak in comparison to the previous pretreatment stage (Table 2). This decrease might indicate the degradation of lignin during the enzymatic pretreatment. The only exception was nitric acid, whose lignin peak showed an area increase. Hirata and Nishimoto (1991) observed that DSC peaks in cellulose samples treated with different inorganic compounds experienced shifts to lower temperatures and increases or decreases of enthalpy. It has been reported that the presence of ashes or inorganic salts in biomass reduces the onset temperature of these thermal reactions (Várhegyi et al. 1997). This could explain the abnormal observations recorded for nitric acid; and lignin degradation with this specific treatment cannot be discarded. In the endothermic region $\left(<270{ }^{\circ} \mathrm{C}\right)$, the inflexion point of most curves moved to lower temperatures, in the range of $90-110{ }^{\circ} \mathrm{C}$. This could suggest the hypothetical disappearance of cellulose from the treated samples, since cellulose degradation is an endothermic process with a shallow and broad peak at $200-300{ }^{\circ} \mathrm{C}$ (Hirata and Nishimoto 1991). 


\section{Acknowledgments}

The authors thank Novozymes for kindly providing samples of their enzymes. Authors thank R. Antón del Río, N. del Castillo Ferreras and G. Sarmiento Martínez for their technical help.

\section{Compliance with ethical standards}

\section{Funding}

The present work has been performed as part of the H2020-LCE-2015 Waste2Fuels project (Sustainable production of next generation biofuels from waste streams Waste2Fuels; GA - 654623), funded by the European Union's Horizon 2020 Research and Innovation Programme. MH-V is supported by a postdoctoral contract (DOC-INIA, grant number DOC 2013-010) funded by the Spanish Agricultural and Agrifood Research Institute (INIA) and the European Social Fund.

\section{Conflict of Interest}

The authors declare that they have no conflict of interest.

\section{Ethical approval}

This article does not contain any studies with human participants or animals performed by any of the authors.

\section{References}

Amiri H, Karimi K (2015) Autohydrolysis: A promising pretreatment for the improvement of acetone, butanol, and ethanol production from woody materials. Chem Eng Sci 137: 722-729. doi: 10.1016/j.ces.2015.07.020.

Araque E, Parra C, Freer J, Contreras D, Rodríguez J, Mendonça R, Baeza J (2008) Evaluation of organosolv pretreatment for the conversion of Pinus radiata D. Don to ethanol. Enzyme Microb Tech 43: 214-219. doi: 10.1016/j.enzmictec.2007.08.006.

Buruiana C-T, Vizireanu C, Garrote G, Parajó JC (2014) Optimization of corn stover biorefinery for coproduction of oligomersand second generation bioethanol using non-isothermalautohydrolysis. Ind Crop Prod 54: 32-39. doi: 10.1016/j.indcrop.2014.01.003.

Chen J-S, Zidwick MJ, Rogers P (2013) Organic acid and solvent production: Butanol, acetone and isopropanol; 1,3- and 1,2-propanediol production; and 2,3-butanediol production. In: Rosenberg E, DeLong EF, Lory S, Stackebrandt E, Thompson F (eds.) The Prokaryotes-Applied Bacteriology and Biotechnology. Springer-Verlag, Heidelberg, pp. 77-134.

Cho DH, Lee YJ, Um Y, Sang BI, Kim YH (2009) Detoxification of model phenolic compounds in lignocellulosic hydrolysates with peroxidase for butanol production from Clostridium beijerinckii. Appl Microbiol Biot 83: 1035-1043. doi: 10.1007/s00253-009-1925-8.

Ćosić B, Pukšec T, Krajačić G, Duić N, Markovska N, Mikulčić H, Vujanović M (2016) Database/Inventory of the FRUIT AWCB value chain. AgroCycle. http://www.agrocycle.eu/documents/. Accessed in April 2017.

Dhillon GS, Kaur S, Brar SK (2013) Perspective of apple processing wastes as low-cost substrates for bioproduction of high value products: A review. Renew Sust Energ Rev 27: 789-805. doi: 10.1016/j.rser.2013.06.046. 
Dien BS, Jung H-JG, Vogel KP, Casler MD, Lamb JAFS, Iten L, Mitchell RB, Sarath G (2006) Chemical composition and response to dilute-acid pretreatment and enzymatic saccharification of alfalfa, reed canarygrass, and switchgrass. Biomass Bioenerg 30: 880-891. doi: 10.1016/j.biombioe.2006.02.004.

Díez-Antolínez R, Hijosa-Valsero M, Paniagua-García AI, Gómez X (2016) Effect of nutrient supplementation on biobutanol production from cheese whey by $\mathrm{ABE}$ (acetone-butanol-ethanol) fermentation. Chem Engineer Trans 49: 217-222. doi: 10.3303/CET1649037.

Ezeji T, Qureshi N, Blaschek HP (2007) Butanol production from agricultural residues: Impact of degradation products on Clostridium beijerinckii growth and butanol fermentation. Biotechnol Bioeng 97: 1460-1469. doi: 10.1002/bit.21373.

FAOSTAT (2016) Statistics of the Food and Agriculture Organisation of the United Nations, http://www.fao.org/faostat/en/\#data (Last accessed in March 2017)

Folin O, Denis W (1912) On phosphotungstic-phosphomolybdic compounds as color reagents. J Biol Chem 12: 239-243.

Gama R, van Dyk JS, Pletschke BI (2015) Optimisation of enzymatic hydrolysis of apple pomace for production of biofuel and biorefinery chemicals using commercial enzymes. 3 Biotech 5: 1075-1087. doi: 10.1007/s13205-015-0312-7.

Gao K, Rehman L (2014) ABE fermentation from enzymatic hydrolysate of $\mathrm{NaOH}-$ pretreated corncobs. Biomass Bioenerg 66: 110-115. doi: 10.1016/j.biombioe.2014.03.002.

Garrote G, Domínguez H, Parajó JC (1999) Mild autohydrolysis: an environmentally friendly technology for xylooligosaccharide production from wood. J Chem Technol Biot 74: 1101-1109. doi: 10.1002/(SICI)1097-4660(199911)74:11<1101::AIDJCTB146>3.0.CO;2-M.

Gonçalves FA, Ruiz HA, dos Santos ES, Teixeira JA, de Macedo GR (2015) Bioethanol production from coconuts and cactus pretreated by autohydrolysis. Ind Crop Prod 77: 1-12. doi: 10.1016/j.indcrop.2015.06.041.

Guilherme AA, Dantas PVF, Santos ES, Fernandes FAN, Macedo GR (2015) Evaluation of composition, characterization and enzymatic hydrolysis of pretreated sugar cane bagasse. Braz J Chem Eng 32: 23-33. Doi: 10.1590/0104$6632.20150321 \mathrm{~s} 00003146$.

Hirata T, Nishimoto T (1991) DSC, DTA, and TG of cellulose untreated and treated with flame-retardants. Thermochim Acta 193: 99-106. doi: 10.1016/00406031(91)80177-K.

He F, Yi W, Bai X (2006) Investigation on caloric requirement of biomass pyrolysis using TG-DSC analyzer. Energ Convers Manage 47: 2461-2469. doi: 10.1016/j.enconman.2005.11.011.

Jang Y-S, Malaviya A, Cho C, Lee J, Lee SY (2012) Butanol production from renewable biomass by Clostridia. Bioresource Technol 123: 653-663. doi: 10.1016/j.biortech.2012.07.104.

Jesse TW, Ezeji TC, Qureshi N, Blaschek HP (2002) Production of butanol from starchbased waste packing peanuts and agricultural waste. J Ind Microbiol Biot 29: 117123. doi: $10.1038 /$ sj.jim.7000285.

Jones DT, Woods DR (1986) Acetone-butanol fermentation revisited. Microbiol Rev 50: 484-524.

Jurgens G, Survase S, Berezina O, Sklavounos E, Linnekoski J, Kurkijärvi A, Väkevä M, van Heiningen A, Granström T (2012) Butanol production from lignocellulosics. Biotechnol Lett 34: 1415-1434. doi: 10.1007/s10529-012-0926-3. 
Kapu NUS, Manning M, Hurley TB, Voigt J, Cosgrove DJ, Romaine CP (2012) Surfactant-assisted pretreatment and enzymatic hydrolysis of spent mushroom compost for the production of sugars. Bioresource Technol 114: 399-405. doi: 10.1016/j.biortech.2012.02.139.

Kótai L, Szépvölgyi J, Szilágyi M, Zhibin L, Baiquan C, Sharma V, Sharma PK (2013) Biobutanol from renewable agricultural and lignocellulose resources and its perspectives as alternative of liquid fuels. In: Fang Z (ed.) Liquid, Gaseous and Solid Biofuels-Conversion Techniques. InTech, Rijeka, pp. 199-262.

Kurabi A, Berlin A, Gilkes N, Kilburn D, Bura R, Robinson J, Markov A, Skomarovsky A, Gusakov A, Okunev O, Sinitsyn A, Gregg D, Xie D, Saddler J (2005) Enzymatic hydrolysis of steam-exploded and ethanol organosolv-pretreated Douglas-fir by novel and commercial fungal cellulases. Appl Biochem Biotech 121-124: 219-230. doi: 10.1385/ABAB:121:1-3:0219.

Lee JM, Shi J, Venditti RA, Jameel H (2009) Autohydrolysis pretreatment of Coastal Bermuda grass for increased enzyme hydrolysis. Bioresource Technol 100: 64346441. doi: $10.1016 /$ j.biortech.2008.12.068.

Lloyd TA, Wyman CE (2005) Combined sugar yields for dilute sulfuric acid pretreatment of corn stover followed by enzymatic hydrolysis of the remaining solids. Bioresource Technol 96: 1967-1977. doi: 10.1016/j.biortech.2005.01.011.

Maiti S, Sarma SJ, Brar SK, Le Bihan Y, Drogui P, Buelna G, Verma M (2016) Agroindustrial wastes as feedstock for sustainable bio-production of butanol by Clostridium beijerinckii. Food Bioprod Process 98: 217-226. doi: 10.1016/j.fbp.2016.01.002.

Mesa L, González E, Cara C, González M, Castro E, Mussatto SI (2011) The effect of organosolv pretreatment variables on enzymatic hydrolysis of sugarcane bagasse. Chem Eng J 168: 1157-1162. doi: 10.1016/j.cej.2011.02.003.

NREL (2008) Determination of ash in biomass. Laboratory Analytical Procedure (LAP). Technical Report NREL/TP-510-42622. http://www.nrel.gov/docs/gen/fy08/42622.pdf, Accessed in May 2017.

NREL (2012) Determination of structural carbohydrates and lignin in biomass. Laboratory Analytical Procedure (LAP). Technical Report NREL/TP-510-42618 http://www.nrel.gov/docs/gen/fy13/42618.pdf, Accessed in May 2017.

Obama P, Ricochon G, Muniglia L, Brosse N (2012) Combination of enzymatic hydrolysis and ethanol organosolv pretreatments: Effect on lignin structures, delignification yields and cellulose-to-glucose conversion. Bioresource Technol 112: 156-163. doi: 10.1016/j.biortech.2012.02.080.

Orozco AM, Al-Muhtaseb AH, Rooney D, Walker GM, Ahmad MNM (2013) Hydrolysis characteristics and kinetics of waste hay biomass as a potential energy crop for fermentable sugars production using autoclave Parr reactor system. Ind Crop Prod 44: 1-10. doi: 10.1016/j.indcrop.2012.10.018.

Paniagua-García AI, Díez-Antolínez R, Sánchez-Morán ME, Coca-Sanz M, HijosaValsero M (in preparation) Butanol production from dilute sulfuric acid hydrolysate of switchgrass by Clostridium beijerinckii: Effect of inhibitors and sugars concentration.

Qureshi N, Saha BC, Hector RE, Dien B, Hughes S, Liu S, Iten L, Bowman MJ, Sarath G, Cotta MA (2010) Production of butanol (a biofuel) from agricultural residues: Part II - Use of corn stover and switchgrass hydrolysates. Biomass Bioenerg 34: 566571. doi: 10.1016/j.biombioe.2009.12.023. 
Salehi Jouzani G, Taherzadeh MJ (2015) Advances in consolidated bioprocessing systems for bioethanol and butanol production from biomass: a comprehensive review. Biofuel Research Journal 5: 152-195. doi: 10.18331/BRJ2015.2.1.4.

Sudha ML, Baskaran V, Leelavathi K (2007) Apple pomace as a source of dietary fiber and polyphenols and its effect on the rheological characteristics and cake making. Food Chem 104: 686-692. doi: 10.1016/j.foodchem.2006.12.016.

Sun Y, Jin Y, Gao X, Li X, Xiao Y, Yao Z (2010) Effects of byproducts from acid hydrolysis of lignocelluloses on butanol fermentation by Clostridium acetobutylicum CICC8012. Chinese J Appl Environ Biol 16(6): 845-850. doi: 10.3724/SP.J.1145.2010.00845.

Tahir A, Sarwar S (2012) Effect of cultural condition on production of ethanol from rotten apple waste by Saccharomyces cerevisiae straining. Can J App Sci 2: 187-195.

Várhegyi G, Antal Jr. MJ, Jakab E, Szabó P (1997) Kinetic modeling of biomass pyrolysis. J Anal Appl Pyrol 42: 73-87. doi: 10.1016/S0165-2370(96)00971-0.

Voget CE, Mignone CF, Ertola RJ (1985) Butanol production from apple pomace. Biotechnol Lett 7: 43-46. doi: 10.1007/BF01032418.

Wei L, Shrestha A, Tu M, Adhikari S (2011) Effects of surfactant on biochemical and hydrothermal conversion of softwood hemicellulose to ethanol and furan derivatives. Process Bioch 46: 1785-1792. doi: 10.1016/j.procbio.2011.06.001.

Xu YP, Simon JE, Welch C, Wightman JD, Ferruzzi MG, Ho L (2011) Survey of polyphenol constituents in grapes and grape-derived products. J Agr Food Chem 59: 10586-10593. doi: 10.1021/jf202438d.

Yang H, Yan R, Chen H, Lee DH, Zheng C (2007) Characteristics of hemicellulose, cellulose and lignin pyrolysis. Fuel 86: 1781-1788. doi: 10.1016/j.fuel.2006.12.013.

Zhang Y, Han B, Ezeji TC (2012) Biotransformation of furfural and 5-hydroxymethyl furfural (HMF) by Clostridium acetobutylicum ATCC 824 during butanol fermentation. New Biotechnol 29: 345-351. doi: 10.1016/j.nbt.2011.09.001.

Zverlov VV, Berezina O, Velikodvorskaya GA, Schwarz WH (2006) Bacterial acetone and butanol production by industrial fermentation in the Soviet Union: use of hydrolyzed agricultural waste for biorefinery. Appl Microbiol Biot 71: 587-597. doi: $\underline{10.1007 / \mathrm{s} 00253-006-0445-\mathrm{z} .}$

\section{Disclaimer:}

This document is a pre-print version of the manuscript that was subsequently peer-reviewed and accepted for publication by the journal Applied Microbiology and Biotechnology (2017). The final publication is available at Springer via http://dx.doi.org/10.1007/s00253-017-8522-z. 